\title{
Glucose level evaluation in monopedicled rectus abdominis myocutaneous flap after venous occlusion: experimental study in rats
}

\section{Avaliação do nível glicêmico em retalho miocutâneo do reto abdominal monopediculado após oclusão venosa: estudo experimental em ratos.}

\author{
Gustavo levacov Berlimi'; Antônio Carlos Pinto Oliveira²; Ciro Paz Portinho²; Emerson Morello; Carolina Barbi Linhares³; Marcus \\ Vinicius Martins Collares'
}

\section{A B S T R A C T}

\begin{abstract}
Objective: to validate an experimental model for the measurement of glycemic levels in surgical flaps with the use of common glucometers, and to analyze the diagnostic criteria for hypoperfusion of such flaps. Methods: we performed vertical myocutaneous rectus abdominis flaps with upper pedicles bilaterally in 20 male Wistar rats, divided into two groups: with and without venous occlusion of the pedicle. We measured glucose levels in the flaps and in the systemic circulation with standard glucometers. We tested the accuracy of alternative diagnostic criteria for the detection of hypoperfusion. Results: from 15 minutes of venous occlusion on, there was a significant reduction in glucose levels measured in the congested flap ( $p<0.001)$. Using a minimum difference of $20 \mathrm{mg} / \mathrm{dl}$ in the glycemic levels between the flap and systemic blood, 30 minutes after occlusion, as a diagnostic criterion, the sensitivity was 100\% (95\% Cl 83.99-100\%) and specificity of $90 \%$ (95\% Cl 69.90-97.21\%) for the diagnosis of flap congestion. Conclusion: It is possible to measure glucose levels in vertical myocutaneous rectus abdominis flaps of Wistar rats, perfused or congested, using a common glucometer. The diagnostic criteria that compare the glucose levels in the flaps with the systemic ones were more accurate in the evaluation of tissue perfusion.
\end{abstract}

Keywords: Models, Animal. Glucose. Perfusion. Surgical Flaps. Diagnosis.

\section{INTRODUCTION}

$\mathrm{O}$ ne of the most common complications of flap surgery is the occlusion of the pedicle vessels with subsequent necrosis of the flap, which occurs in $3 \%$ to $7 \%$ of cases, even with advanced surgical techniques ${ }^{1-8}$. Therefore, perfusion monitoring is essential, since early reoperation is the best option to recover a low perfusion flap, the diagnosis of which is usually made through clinical evaluation of the flap by a member of the surgical team ${ }^{2,4-8}$. Many methods have been tested with the aim of obtaining the early diagnosis of hypoperfusion, also capable of allowing an objective evaluation by other, non-specialist professionals. Among these evaluations are temperature measurement, Doppler flowmetry, transcutaneous oximetry, and tissue glucose and metabolic levels $s^{6,7,9-16}$. The latter are highly efficient in the evaluation of flap perfusion, although some measurement methods are costly and require the use of special equipment $14,15,17-20$. The common glucometer, which uses a drop of blood, is a low-cost method for measuring glucose and is readily available in most hospital units. It is an easy, fast, objective and inexpensive method to measure glycemic levels.

Although glycemic levels are a widely accepted way of monitoring flaps, there is no consensus as to the appropriate levels for the diagnosis of hypoperfusion. Sitzman et al. ${ }^{19}$ observed that the rate of reduction of glycemic levels is more accurate in the diagnosis of hypoperfusion than one isolated glucose measurement.

The objective of this study is to validate an experimental model that uses a common glucometer to measure glucose in a vertical rectus abdominis myocutaneous (VRAM) flap in Wistar rats. We also tested the accuracy of diagnostic criteria that compare glucose levels in flaps with systemic levels.

1 - Federal University of Rio Grande do Sul (UFRGS), Post-Graduate Program in Surgical Sciences, Medical School, Porto Alegre, RS, Brazil. 2 - Porto Alegre Clinics Hospital (HCPA), Plastic Surgery Service, Porto Alegre, RS, Brazil. 3 - Federal University of Rio Grande do Sul (UFRGS), Medical School, Porto Alegre, RS, Brazil. 


\section{METHODS}

We conducted an experimental, comparative and controlled study, approved by the Ethics Committee on the Use of Animals, of the Group of Research and Graduate Studies of the Porto Alegre Clinics Hospital, under number 130448.

The sample size was calculated based on the results of an earlier study by Sitzman et al. ${ }^{19}$. Considering a significance level of $5 \%$ and a power of $80 \%$ to detect a difference of $150 \mathrm{mg} / \mathrm{dL}$ of glucose between the groups, with the same standard deviation obtained 15 minutes after the intervention in the aforementioned study, the sample size was estimated in 16 rats (32 flaps). In order to avoid any losses and impairment of the statistical analysis, we decided to include four more animals. We selected 20 male Wistar rats at four months of age and weighing between 400 and $500 \mathrm{~g}$, divided into two groups: intervention group $(n=20)$, with ligation of the superior epigastric vein of the flap, and control group $(n=20)$, without ligation of the superior epigastric vein.

The animals received tramadol hydrochloride $(5 \mathrm{mg} / \mathrm{kg})$ intraperitoneally and underwent general inhalation anesthesia with isoflurane vaporized in 100\% oxygen. The doses specified in the institution's protocol are $100 \mathrm{ml} / \mathrm{min}$ for induction and $30 \mathrm{ml} / \mathrm{min}$ for maintenance of anesthesia. We placed the rats in dorsal decubitus on thermal plates and performed abdominal trichotomy. We dissected bilateral VRAM flaps, as previously described ${ }^{21-24}$. The flaps were pediculated exclusively by the superior epigastric vessels, which are the dominant pedicle of the rectus abdominis muscle in rats ${ }^{22,23}$. The abdominal cavity was protected with a plastic field to reduce heat loss and dryness of the viscera. We dissected the pedicle containing the upper epigastric vessels with microsurgical instruments and under five-times magnification. We chose the side on which we ligated and divided the epigastric vein based on a previously defined random sequence. This sequence was generated at www.sealedenvelope. com. We dissected the vascular pedicle of the control flap and kept it intact (Figure 1).

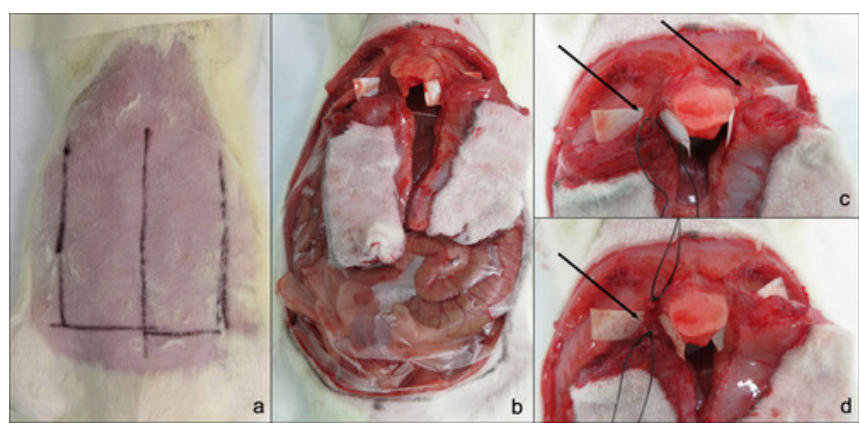

Figure 1. a) Marked flaps. b) Dissected flaps. c) Dissected superior epigastric vein. d) Ligated and divided upper epigastric vein.

We measured interstitial glucose in the flaps every 15 minutes, from time zero (before ligation and division of the superior epigastric vein) to 60 minutes, through the puncture of a vein located in the posterior aspect of the flap. We also measured glycemia at the same time intervals in the rats' caudal vein (systemic control, $\mathrm{n}=20$ ). We measured glucose levels with the MediSense Optimum glucometer.

We performed euthanasia at the end of the experiment with isoflurane overdose, capable of inducing cardiac arrest, followed by exanguination. We followed all biosafety regulations, as well as the ethical aspects relevant to animal research.

We performed statistical analysis using a model of generalized estimating equation ${ }^{25}$, comparing measurement times and groups (congestive flap, control flap and systemic control) and the interaction between measurement times and groups. We expressed glycemic levels as mean \pm standard deviation. For diagnostic analysis, we used the Receiver Operating Characteristic (ROC) curve to determine cutoff points. For these points, we calculated the sensitivity and specificity values, as well as their $95 \%$ confidence intervals $(95 \% \mathrm{Cl})$. We considered values of $p$ less than $5 \%$ as significant. We performed calculations using the SPSS v.22 and WinPEPI v.11.39 softwares.

\section{RESULTS}

Systemic glucose remained stable throughout the experiment in all animals. Glycemic levels fell rapidly after venous occlusion in the intervention group and remained stable in the control group. From 15 minutes 
after venous occlusion on, the glycemic levels of the intervention group flaps were significantly lower than those of the control and systemic blood flaps (Figure 2).

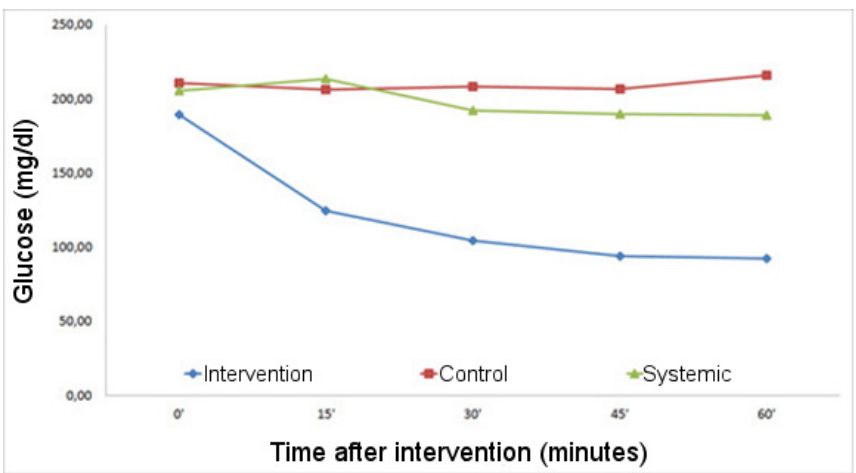

Figure 2. Mean glucose levels.

We performed an intragroup analysis to compare glycemic levels prior to venous occlusion (zero time) with those of subsequent measurement times. We found significant differences only in the intervention group.

To assess the diagnostic criteria for congestion, we used glycemic values of 30 minutes after venous occlusion, because at that moment the levels began to stabilize in the flaps submitted to the intervention. We calculated three ROC curves: glycemic levels, the difference between the flap and systemic glucose levels (measured value in the flap minus that measured in the tail) and the relationship between the flap and systemic glucose levels (value measured in the flap divided by the value measured in the tail). The areas under the curve were, respectively, $0.925,0.975$ and 0.980 (Figure 3).

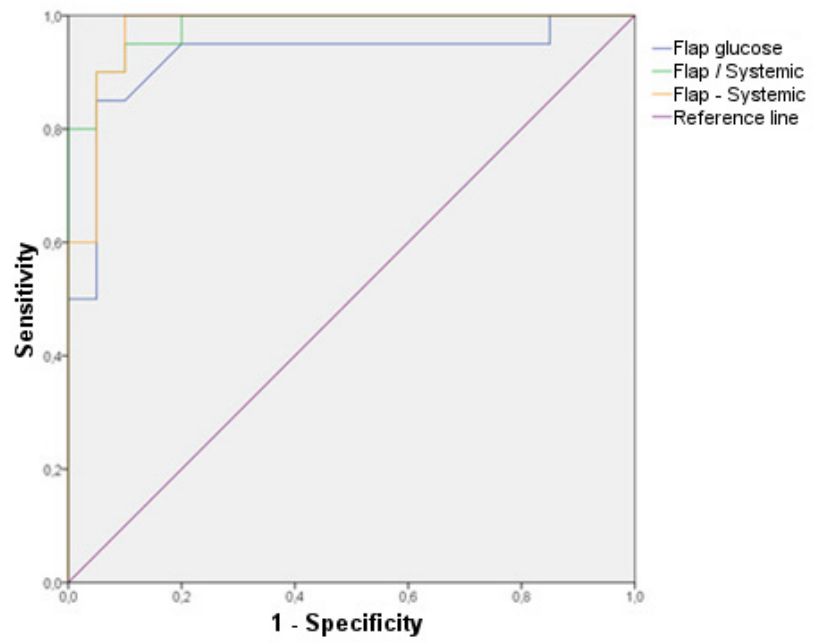

Figure 3. ROC curve.
From the ROC curves, we determined the cutoff points. Using glycemic levels in the flap as a diagnostic test with a cutoff value of $153 \mathrm{mg} / \mathrm{dl}$, the sensitivity was 90\% (95\% Cl 69.90-97.21\%) and 85\% specificity (95\% $\mathrm{Cl}$ 63.96-94.76\%). Using the difference between flap and systemic glucose levels with a cutoff value of $20 \mathrm{mg} / \mathrm{dl}$, the sensitivity was $100 \%$ (95\% Cl 83.89-100.00\%) and the specificity of $90 \%$ (95\% Cl $69.90-97.21 \%$ ). Using the relationship between the flap and systemic glucose levels with a cutoff value of 0.8773 , the sensitivity was $95 \%$ (95\% Cl 76.39-99.11\%) and the specificity was $90 \%$ (95\% Cl 69.90-97.21\%).

\section{DISCUSSION}

The measurement of glycemic levels in VRAM flaps of Wistar rats was possible using a common glucometer, as well as the detection of a drop in glycemic levels in congested flaps. The results were comparable to those obtained by Sitzman et al. ${ }^{19}$, who used an implantable glucometer. However, glucometers are readily available in all hospital units. During the study, we observed that there was little, if any, bleeding in the cutaneous lesions. To obtain a drop of blood for the measurement of glucose level in the flap, we performed a puncture injury on a vein on the posterior aspect of the flap.

The results obtained in this study are comparable to those observed in previous ones that measured the glycemic levels of the flaps using implantable glucometers ${ }^{19}$ or microdialysis ${ }^{14,15,17,18,20}$. We identified no previous experimental studies with glucose dosage by glucometers, this aspect being the novelty of this work. This validates the present experimental model as an alternative to those who used implantable meters ${ }^{14}$.

In most clinical studies, glycemic values in the flap are used alone for monitoring. In this study, criteria using comparative glucose levels were more accurate than the isolated use of glycemic levels in the diagnosis of flap congestion. This higher precision can be observed by the sensitivity and specificity values and the ROC curve, in which the comparative criteria presented a larger area under the curve.

In a series of 33 flaps, Hara et al. ${ }^{26}$ used glucometers to monitor postoperative glucose levels. 
A cut-off value of $62 \mathrm{mg} / \mathrm{dL}$ was established for the diagnosis of vascular obstruction in the pedicle, resulting in a sensitivity of $88 \%$ and a specificity of $82 \%$. Using the same cutoff value, Bashir et al. ${ }^{27}$ obtained a sensitivity of $90 \%$ and a specificity of $78 \%$ in a prospective study with 127 flaps. In a French multicenter study, Henault et al. ${ }^{28}$ evaluated free flaps in 37 patients. Tissue levels of glucose and lactate and hypoperfusion were measured using cutoff values of $69.37 \mathrm{mg} / \mathrm{dL}$ for glucose and $57.66 \mathrm{mg} /$ $\mathrm{dL}$ for lactate. Based on these criteria, they obtained a sensitivity of $98.5 \%$ and a specificity of $99.5 \%$, and hypoperfusion was diagnosed approximately 5.4 hours prior to diagnosis based on the clinical evaluation.

Akita et al. ${ }^{29}$ conducted a study comparing tissue oximetry and tissue glucose levels in flaps. For both evaluations, they used indices comparing the values obtained in the flaps with those obtained in another nonoperated site of the body. In that study, both evaluations were efficient, but tissue oximetry provided an earlier diagnosis. The main limitation in the use of glucometers is that they do not work in ischemic flaps, which receives less blood and therefore will not bleed. As a result, a needle puncture wound on the flap will not produce the drop of blood needed to measure glycemic levels. If a drop of blood is produced in the ischemic flap, it comes from the retrograde venous blood flow, which will not reflect the glycemic levels in the flap $15,19,20$.

It could also be considered a limitation of this study to not follow the animals for a longer period to verify the clinical outcome in the flaps studied. However, as the flaps were pediculated exclusively by the superior epigastric vessels, it is reasonable to assume that all the flaps in the intervention group would undergo complete necrosis.

We conclude that tissue glucose levels of perfused and congested VRAM flaps in Wistar rats can be adequately measured with a common glucometer. Comparison of glucose levels of the flap with the systemic ones appears to be more accurate in the diagnosis of congestion than the isolated flap levels.

\title{
R E S U M O
}

\begin{abstract}
Objetivo: validar um modelo experimental para mensuração de níveis glicêmicos em retalhos cirúrgicos com a utilização de glicosímetros comuns, e analisar os critérios diagnósticos para hipoperfusão destes retalhos. Métodos: foram realizados retalhos miocutâneos verticais de reto abdominal com pedículos superiores, bilateralmente, em 20 ratos Wistar machos, divididos em dois grupos: com e sem oclusão venosa do pedículo. Os níveis de glicose foram mensurados nos retalhos e na circulação sistêmica com glicosímetros comuns. A acurácia de critérios diagnósticos alternativos foi testada para a detecção de hipoperfusão. Resultados: a partir de 15 minutos de oclusão venosa, houve uma redução significativa dos níveis de glicose medidos no retalho congesto $(p<0,001)$. Utilizando como critério diagnóstico uma diferença mínima de $20 \mathrm{mg} / \mathrm{dl}$ nos níveis glicêmicos do retalho e do sangue sistêmico, 30 minutos após a oclusão, a sensibilidade foi de $100 \%$ (intervalo de confiança de $95 \%$ - 83,99 a 100\%) e especificidade de 90\% (intervalo de confiança de $95 \%$ - 69,90 a 97,21\%) para o diagnóstico de congestão do retalho. Conclusão: os resultados demonstraram que é possível medir níveis de glicose em retalhos miocutâneos verticais de reto abdominal de ratos Wistar, perfundidos ou congestos, utilizando um glicosímetro comum. Os critérios diagnósticos que comparam os níveis de glicose nos retalhos com os níveis sistêmicos foram mais precisos na avaliação da perfusão tecidual.
\end{abstract}

Descritores: Modelos Animais. Perfusão. Retalhos Cirúrgicos. Glucose. Diagnóstico.

\section{REFERENCES}

1. Glicksman A, Ferder M, Casale P, Posner J, Kim R, Strauch B. 1457 years of microsurgical experience. Plast Reconstr Surg. 1997;100(2):355-63.

2. Bui DT, Cordeiro PG, Hu QY, Disa JJ, Pusic A, Mehrara BJ. Free flap reexploration: indications, treatment, and outcomes in 1193 free flaps. Plast Reconstr Surg. 2007;119(7):2092-100.
3. Gill PS, Hunt JP, Guerra AB, Dellacroce FJ, Sullivan SK, Boraski J, et al. A 10-year retrospective review of 758 DIEP flaps for breast reconstruction. Plast Reconstr Surg. 2004;113(4):1153-60.

4. Kroll SS, Schusterman MA, Reece GP, Miller MJ, Evans $\mathrm{GR}$, Robb GL, et al. Timing of pedicle thrombosis and flap loss after free-tissue transfer. Plast Reconstr Surg. 1996;98(7):1230-3. 
5. Brown JS, Devine JC, Magennis $P$, Sillifant $P$, Rogers $\mathrm{SN}$, Vaughan ED. Factors that influence the outcome of salvage in free tissue transfer. Br J Oral Maxillofac Surg. 2003;41(1):16-20.

6. Jallali N, Ridha H, Butler PE. Postoperative monitoring of free flaps in UK plastic surgery units. Microsurgery. 2005;25(6):469-72.

7. Disa JJ, Cordeiro PG, Hidalgo DA. Efficacy of conventional monitoring techniques in free tissue transfer: an 11-year experience in 750 consecutive cases. Plast Reconstr Surg. 1999;104(1):97-101.

8. Chubb D, Rozen WM, Whitaker IS, Acosta R, Grinsell $D$, Ashton MW. The efficacy of clinical assessment in the postoperative monitoring of free flaps: a review of 1140 consecutive cases. Plast Reconstr Surg. 2010;125(4):1157-66.

9. Kraemer R, Lorenzen J, Knobloch K, Papst S, Kabbani $M$, Koennecker $S$, et al. Free flap microcirculatory monitoring correlates to free flap temperature assessment. J Plast Reconstr Aesthet Surg. 2011;64(10):1353-8.

10. Kind GM, Buntic RF, Buncke GM, Cooper TM, Siko PP, Buncke HJ Jr. The effect of an implantable Doppler probe on the salvage of microvascular tissue transplants. Plast Reconstr Surg. 1998;101(5):126873; discussion 1274-5.

11. Gimbel ML, Rollins MD, Fukaya E, Hopf HW. Monitoring partial and full venous outflow compromise in a rabbit skin flap model. Plast Reconstr Surg. 2009;124(3):796-803.

12. Keller A. A new diagnostic algorithm for early prediction of vascular compromise in 208 microsurgical flaps using tissue oxygen saturation measurements. Ann Plast Surg. 2009;62(5):538-43.

13. Russell JA, Conforti ML, Connor NP, Hartig GK. Cutaneous tissue flap viability following partial venous obstruction. Plast Reconstr Surg. 2006;117(7):2259-66; discussion 2267-8.

14. Contaldo C, Plock J, Djonov V, Leunig M, Banic A, Erni $D$. The influence of trauma and ischemia on carbohydrate metabolites monitored in hamster flap tissue. Anesth Analg. 2005;100(3):817-22.

15. Setälä LP, Korvenoja EM, Härmä MA, Alhava EM, Uusaro AV, Tenhunen JJ. Glucose, lactate, and pyruvate response in an experimental model of microvascular flap ischemia and reperfusion: a microdialysis study. Microsurgery. 2004;24(3):22331.

16. Jyränki J, Suominen S, Vuola J, Bäck L. Microdialysis in clinical practice: monitoring intraoral free flaps. Ann Plast Surg. 2006;56(4):387-93.

17. Röjdmark J, Ungerstedt J, Blomqvist L, Ungerstedt $U$, Hedén P. Comparing metabolism during ischemia and reperfusion in free flaps of different tissue composition. Eur J Plast Surg. 2002;24(7):349-55.

18. Röjdmark J, Hedén $P$, Ungerstedt U. Microdialysis - a new technique for free flap surveillance: methodological description. Eur J Plast Surg. 1998;21(7):344-8.

19. Sitzman TJ, Hanson SE, King TW, Gutowski KA. Detection of flap venous and arterial occlusion using interstitial glucose monitoring in a rodent model. Plast Reconstr Surg. 2010;126(1):71-9.

20. Röjdmark J, Hedén P, Ungerstedt U. Comparison of flap ischemia induced by arterial or venous occlusion in pigs with the aid of microdialysis. Eur J Plast Surg. 2000;23(5):278-82.

21. Dunn RM, Mancoll J. Flap models in the rat: a review and reappraisal. Plast Reconstr Surg. 1992;90(2):31928.

22. Ozgentas HE, Shenaq S, Spira M. Development of a TRAM flap model in the rat and study of vascular dominance. Plast Reconstr Surg. 1994;94(7):10127; 1025-6 discussion.

23. Hallock GG, Rice DC. Physiologic superiority of the anatomic dominant pedicle of the TRAM flap in a rat model. Plast Reconstr Surg. 1995;96(1):111-8.

24. Dunn RM, Huff W, Mancoll J. The rat rectus abdominis myocutaneous flap: a true myocutaneous flap model. Ann Plast Surg. 1993;31(4):352-7.

25. Guimarães LS, Hirakata VN. Uso do Modelo de Equações de Estimativas Generalizadas na análise de dados longitudinais. Rev HCPA. 2012;32(4):503-11.

26. Hara $H$, Mihara $M$, lida $T$, Narushima $M$, Todokoro $T$, Yamamoto $T$, et al. Blood glucose measurement for flap monitoring to salvage flaps from venous thrombosis. J Plast Reconstr Aesthet Surg. 2012;65(5):616-9. 
27. Bashir MM, Tayyab Z, Afzal S, Khan FA. Diagnostic accuracy of blood glucose measurements in detecting venous compromise in flaps. J Craniofac Surg. 2015;26(5):1492-4.

28. Henault B, Pluvy I, Pauchot J, Sinna R, LabruèreChazal C, Zwetyenga N. Capillary measurement of lactate and glucose for free flap monitoring. Ann Chir Plast Esthet. 2014;59(1):15-21.

29. Akita S, Mitsukawa N, Tokumoto H, Kubota Y, Kuriyama M, Sasahara $Y$, et al. Regional Oxygen Saturation Index: a novel criterion for free flap assessment using tissue oximetry. Plast Reconstr Surg. 2016;138(3):510e-8e.
Received in: 03/08/2017

Accepted for publication: 17/09/2017

Conflict of interest: none.

Source of funding: Research and Events Incentive Fund (FIPE) of the Porto Alegre Clinics Hospital (number:

130448).

\section{Mailing address:}

Gustavo Levacov Berlim

E-mail: gustavoberlim@gmail.com /

formato@scientific.com.br

\section{(cc) BY}

